\title{
Agricultural residues for cellulolytic enzyme production by Aspergillus niger: effects of pretreatment
}

\author{
Aliyu Salihu ${ }^{1}$ - Olagunju Abbas ${ }^{1}$ Abdullahi Balarabe Sallau ${ }^{1} \cdot$ Md. Zahangir Alam ${ }^{2}$
}

Received: 31 October 2014/Accepted: 6 March 2015/Published online: 27 March 2015

(c) The Author(s) 2015. This article is published with open access at Springerlink.com

\begin{abstract}
Different agricultural residues were considered in this study for their ability to support cellulolytic enzyme production by Aspergillus niger. A total of eleven agricultural residues including finger millet hulls, sorghum hulls, soybean hulls, groundnut husk, banana peels, corn stalk, cassava peels, sugarcane bagasse, saw dust, rice straw and sheanut cake were subjected to three pretreatment (acid, alkali and oxidative) methods. All the residues supported the growth and production of cellulases by A. niger after $96 \mathrm{~h}$ of incubation. Maximum cellulase production was found in alkali-treated soybean hulls with CMCase, FPase and $\beta$-glucosidase yields of $9.91 \pm 0.04$, $6.20 \pm 0.13$ and $5.69 \pm 0.29 \mathrm{U} / \mathrm{g}$, respectively. Further studies in assessing the potential of soybean hulls are being considered to optimize the medium composition and process parameters for enhanced cellulase production.
\end{abstract}

Keywords Agricultural residues - Aspergillus niger . Cellulase $\cdot$ Pretreatment

\section{Introduction}

Agricultural residues represent vast raw materials that can be utilized for production of value-added products. The major components of these raw materials, including

Aliyu Salihu

aliyu.salihu@gmail.com

1 Department of Biochemistry, Ahmadu Bello University Zaria, Zaria, Nigeria

2 Department of Biotechnology Engineering, Faculty of Engineering, Bioenvironmental Engineering Research Centre (BERC), International Islamic University Malaysia (IIUM), Gombak, 50728 Kuala Lumpur, Malaysia cellulose $(35-50 \%)$, hemicellulose $(20-35 \%)$, lignin (15-25\%) and a number of other compounds make up the residues (Wyman 1994).

Thus, cellulose being the most abundant polysaccharide constituents of agricultural residues consists of $\beta-1,4$ linear polymers of $8000-12,000$ glucose units. It is mostly found in crystalline, water-insoluble form, and cannot be easily hydrolyzed by most microorganisms (Saha 2004; Clarke 1997).

Some of the microorganisms that have been reported to hydrolyze this insoluble polymer into soluble monomeric units include Bacillus pumilus EB3 (Ariffin et al. 2008), Pseudomonas sp. WLUN024 (Xu et al. 2005), Trichoderma reesei (Wen et al. 2005), Trichoderma harzianum (Alam et al. 2009), Penicillium echinulatum (Sehnem et al. 2006), Aspergillus Phoenicis (Wen et al. 2005), Phanerochaete chrysosporium (Khan et al. 2007) and Aspergillus niger MS82 (Sohail et al. 2009); all of which require the action of cellulases. Cellulase is a multi-component enzyme system that works synergistically in hydrolyzing the cellulosic substrates to glucose. Mostly three enzymes are involved; endo- $\beta$-D-glucanase (EC 3.2.1.4) which catalyzes the random hydrolysis of soluble and insoluble cellulose chains. Exo- $\beta$-D-glucanase (EC 3.2.1.19) aids in releasing cellobiose from reducing and non-reducing ends of cellulose, and hydrolysis of cellobiose to glucose is carried out by $\beta$-glucosidase (EC 3.2.1.37) (Bhat and Bhat 1997; Bhat 2000; Sohail et al. 2009).

Cellulases have been used in a number of industrial processes. The most notable applications are in textile, paper and pulp, food and animal feed, fuel and chemical industry, waste management, and pharmaceutical industry (Bhat 2000; Bhat and Bhat 1997).

Thus, concerted efforts are being made by researchers in exploring different lignocellulosic residues for cellulase 
production using different fermentation techniques. Some of the agricultural residues reported for cellulase production include apple pomace (Dhillon et al. 2012), Coir pith (Jabasingh 2011), oil palm empty fruit bunches (Alam et al. 2009), rice straw (Khan et al. 2007), wheat bran (Xu et al. 2005), switchgrass, corn stover (Zhang et al. 2012), sugarcane bagasse (Maeda et al. 2013), grape pomace (Diaz et al. 2012), rice bran (Liu et al. 2011), corn cobs, rice husk, saw dust and wheat straw (Bansal et al. 2012).

The use of these cheaply available residues contributes to reducing the total enzyme production cost, as raw materials account for up to $40-60 \%$ of the production cost (Wen et al. 2005). Based on this, there is still need for exploring various agricultural residues in order to come up with an effective fermentation medium for cellulase production for wider industrial application.

Additionally, efficient utilization of agricultural residues in bioconversion processes may require different pretreatment techniques, which aid in breaking the lignin seal and distort the organizational structure of complex organic components. Thus, pretreatment of any agricultural residues as described by Sun and Cheng (2002) should not cause degradation of carbohydrate or development of any byproducts that could be inhibitory to the subsequent experimental processes involving hydrolysis and fermentation. Also, improving the formation of sugar hydrolysates by reducing cellulose crystallinity and increasing the porosity of agricultural residues are to be prioritized.

Chemical pretreatment methods have been used in enhancing the bioconversion of lignocellulosic residues for cellulase production. Alkaline pretreatment being the most effective chemical method results in delignification of agricultural residues which leads to breakage of ester bonds cross-linking lignin and xylan, and in effect aids in increasing the porosity of biomass (Sun and Cheng 2002). In case of acid pretreatment, particle size, temperature, reaction time and acid concentration as well as liquid-tosolid ratio are the major factors affecting the process (Zhao et al. 2008). While using $\mathrm{H}_{2} \mathrm{O}_{2}$ aids in delignification of biomass via oxidative reactions to detach and solubilize the lignin by weakening the lignocellulosic matrix, this contributes to improving enzyme digestibility (Silverstein et al. 2007).

The present study was aimed at determining the best substrate (from different agricultural residues) as well as the pretreatment method for cellulolytic enzyme production using A. niger. This is because among the cellulase producing microorganisms, A. niger has been reported to be efficient in the synthesis of all the three cellulolytic enzymes (Sohail et al. 2009). The information obtained in this study would be helpful in developing a cost-effective process for cellulase production.

\section{Materials and methods}

\section{Microorganism}

A. niger used in this study was obtained from culture collection of Department of Crop Protection, Ahmadu Bello University Zaria and maintained on potato dextrose agar slants.

\section{Agricultural residues and pretreatments}

Eleven agricultural residues available in Zaria were collected locally; these include finger millet hulls, sorghum hulls, soybean hulls, groundnut husk, banana peels, corn stalk, cassava peels, sugarcane bagasse, saw dust, rice straw and sheanut cake. The residues were oven-dried in a hot-air oven $\left(60{ }^{\circ} \mathrm{C}\right)$, before being ground and sieved to $1 \mathrm{~mm}$ particle size. The samples were then stored under appropriate conditions in plastic containers until further use. Characterization of these residues was carried out based on sequential fractionation method of Datta (1981) as modified by Arora and Sharma (2009), and the results in terms of cellulose, hemicellulose and lignin were indicated in Table 1.

Acid, alkali and hydrogen peroxide pretreatments of the samples were carried at solid loading of $10 \%(\mathrm{w} / \mathrm{v})$ using $1 \mathrm{~N} \mathrm{H}_{2} \mathrm{SO}_{4}$ and $1 \mathrm{~N} \mathrm{NaOH}$ and $1 \mathrm{~N} \mathrm{H}_{2} \mathrm{O}_{2}$, respectively. The samples were autoclaved for $20 \mathrm{~min}$ at $121{ }^{\circ} \mathrm{C}$ temperature and 15 psi pressure based on the method described by Singh and Bishnoi (2013) with slight modification. The samples were washed repeatedly with water to remove the solvents used for pretreatment and then dried at $60{ }^{\circ} \mathrm{C}$ to a constant weight.

Table 1 Composition of agricultural residues used in this study

\begin{tabular}{llrrr}
\hline $\begin{array}{l}\text { S/ } \\
\text { no. }\end{array}$ & Substrate & $\begin{array}{l}\text { Cellulose } \\
(\%)\end{array}$ & \multicolumn{1}{l}{$\begin{array}{l}\text { Hemicellulose } \\
(\%)\end{array}$} & \multicolumn{1}{l}{$\begin{array}{l}\text { Lignin } \\
(\%)\end{array}$} \\
\hline 1 & Finger millet hulls & $25 \pm 0.73$ & $32 \pm 1.38$ & $4 \pm 1.66$ \\
2 & Sorghum hulls & $39 \pm 0.82$ & $35 \pm 0.07$ & $4 \pm 0.11$ \\
3 & Banana peels & $11 \pm 1.12$ & $9 \pm 0.08$ & $3 \pm 0.55$ \\
4 & Corn stalk & $30 \pm 1.19$ & $33 \pm 2.63$ & $15 \pm 0.67$ \\
5 & Cassava peels & $39 \pm 0.34$ & $25 \pm 0.41$ & $8 \pm 0.52$ \\
6 & Saw dust & $44 \pm 1.77$ & $17 \pm 0.14$ & $21 \pm 1.92$ \\
7 & Sheanut cake & $26 \pm 0.26$ & $9 \pm 0.33$ & $21 \pm 0.09$ \\
8 & Rice straw & $35 \pm 1.31$ & $27 \pm 1.97$ & $16 \pm 2.01$ \\
9 & Soybean hulls & $35 \pm 0.12$ & $16 \pm 0.21$ & $4 \pm 0.19$ \\
10 & Sugarcane bagasse & $45 \pm 0.52$ & $26 \pm 0.34$ & $19 \pm 0.13$ \\
11 & Groundnut husk & $36 \pm 1.41$ & $20 \pm 0.88$ & $25 \pm 1.03$ \\
\hline
\end{tabular}

Values are means \pm standard deviations 


\section{Cellulase production under solid state fermentation}

The target in this study is to select the best substrate as well as pretreatment method for the enzyme production; as such, the substrates were considered with no exogenous addition of any nutrient. Cellulase production experiments were carried in 250-ml Erlenmeyer flask as described by Bansal et al. (2012) containing $5 \mathrm{~g}$ each of the substrate (untreated or treated with acid, alkali and peroxide) of $1 \mathrm{~mm}$ particle size and moistened with distilled water in a ratio of $1: 1.5$. The initial $\mathrm{pH}$ of each set up was fixed at $6.5 \pm 0.1$ by adding few drops of $1 \mathrm{~N} \mathrm{NaOH}$, and the fermentation was carried out under uncontrolled $\mathrm{pH}$ condition.

Following the autoclaving of the flasks at $121{ }^{\circ} \mathrm{C}(15$ psi) for $20 \mathrm{~min}, 7 \mathrm{~mm}$ cut of PDA containing actively growing colonies of 72-h-old culture of A. niger was aseptically added to each flask and incubated at $30{ }^{\circ} \mathrm{C}$ for $96 \mathrm{~h}$ as reported by Bansal et al. (2012). After the fermentation, $50 \mathrm{ml}$ of sterile distilled water was added to each flask and shaken on a rotary shaker $(180 \mathrm{rpm})$ for $1 \mathrm{~h}$. The mixture was centrifuged at $5000 \times g$ for $10 \mathrm{~min}$, and the supernatant was used to assay for the enzyme activity.

\section{Determination of enzyme assays}

The components of the cellulase system which include carboxymethyl cellulase (CMCase), filter paper activity (FPase) and $\beta$-glucosidase were determined based on the methods described by Ghose (1987) and Mandels et al. (1976). One unit (U) of the enzyme was defined as the amount of enzyme that releases $1 \mu \mathrm{mol}$ of reducing sugar per minute from CMC, Whatman filter paper and salicin under standard assay conditions of $0.05 \mathrm{M}$ acetate buffer, $\mathrm{pH} 4.8$ at $50{ }^{\circ} \mathrm{C}$ using dinitrosalicylic acid reagent. The results are expressed in terms of unit per gram of solid substrate $(\mathrm{U} / \mathrm{g})$.

\section{Results and discussion}

Agricultural residues are generated in large quantities in many countries; most of which are underutilized and considered as waste especially in developing countries. Significant efforts have been made by several researchers in converting these residues to valuable products including biofuels, animal feed, biofertilizer, and enzymes. (Dashtban et al. 2009; Sánchez 2009). These processes help in controlling some of the environmental challenges associated with their disposal. The polymeric constituents of agricultural residues used in this study were determined in terms of cellulose, hemicellulose and lignin as presented in Table 1 . This characterization is important in identifying the components that can support the growth of microorganisms for value-added product formation.

The cellulolytic activities in terms of CMCase, FPase and $\beta$-glucosidase obtained in this study were presented in Tables 2, 3, 4 and 5. Interestingly, cellulolytic enzyme activities were recorded in unpretreated residues (Table 2); this indicates that reduction in particle size by milling to $1 \mathrm{~mm}$ can be considered as the first step of pretreatment because it

Table 2 Production of cellulase by A. niger using different agricultural residues without pretreatment

\begin{tabular}{|c|c|c|c|c|}
\hline $\begin{array}{l}\text { S/ } \\
\text { no. }\end{array}$ & $\begin{array}{l}\text { Substrate } \\
\text { (untreated) }\end{array}$ & $\begin{array}{l}\text { CMCase } \\
(\mathrm{U} / \mathrm{g})\end{array}$ & $\begin{array}{l}\text { FPase } \\
(\mathrm{U} / \mathrm{g})\end{array}$ & $\begin{array}{l}\beta \text {-glucosidase } \\
(\mathrm{U} / \mathrm{g})\end{array}$ \\
\hline 1 & $\begin{array}{l}\text { Finger millet } \\
\text { hulls }\end{array}$ & $0.31 \pm 0.10^{\mathrm{a}, \mathrm{b}}$ & $0.25 \pm 0.10^{\mathrm{a}, \mathrm{b}}$ & $0.14 \pm 0.02^{\mathrm{a}}$ \\
\hline 2 & $\begin{array}{l}\text { Sorghum } \\
\text { hulls }\end{array}$ & $0.45 \pm 0.09^{\mathrm{a}, \mathrm{b}}$ & $0.39 \pm 0.09^{\mathrm{b}, \mathrm{c}}$ & $0.21 \pm 0.03^{\mathrm{a}}$ \\
\hline 3 & Banana peels & $0.25 \pm 0.08^{\mathrm{a}}$ & $0.31 \pm 0.08^{\mathrm{a}, \mathrm{b}, \mathrm{c}}$ & $0.67 \pm 0.05^{\mathrm{c}}$ \\
\hline 4 & Corn stalk & $0.71 \pm 0.10^{\mathrm{a}, \mathrm{b}}$ & $0.44 \pm 0.04^{\mathrm{c}}$ & $0.79 \pm 0.09^{\mathrm{d}, \mathrm{e}}$ \\
\hline 5 & $\begin{array}{c}\text { Cassava } \\
\text { peels }\end{array}$ & $1.30 \pm 0.08^{\mathrm{c}, \mathrm{d}, \mathrm{e}}$ & $0.78 \pm 0.07^{\mathrm{d}}$ & $0.59 \pm 0.04^{c}$ \\
\hline 6 & Saw dust & $0.72 \pm 0.10^{\mathrm{b}}$ & $0.47 \pm 0.02^{\mathrm{c}}$ & $0.40 \pm 0.03^{\mathrm{b}}$ \\
\hline 7 & Sheanut cake & $0.09 \pm 0.01^{\mathrm{a}, \mathrm{b}}$ & $0.19 \pm 0.02^{\mathrm{a}}$ & $0.09 \pm 0.01^{\mathrm{a}}$ \\
\hline 8 & Rice straw & $1.76 \pm 0.08^{\mathrm{e}}$ & $1.22 \pm 0.03^{\mathrm{f}}$ & $0.91 \pm 0.04^{\mathrm{e}}$ \\
\hline 9 & $\begin{array}{l}\text { Soybean } \\
\text { hulls }\end{array}$ & $1.29 \pm 0.14^{\mathrm{c}, \mathrm{d}}$ & $0.99 \pm 0.04^{\mathrm{e}}$ & $0.81 \pm 0.01^{\mathrm{e}}$ \\
\hline 10 & $\begin{array}{c}\text { Sugarcane } \\
\text { bagasse }\end{array}$ & $1.66 \pm 0.19^{\mathrm{d}, \mathrm{e}}$ & $1.01 \pm 0.07^{\mathrm{e}}$ & $0.84 \pm 0.01^{\mathrm{e}}$ \\
\hline 11 & $\begin{array}{l}\text { Groundnut } \\
\text { husk }\end{array}$ & $1.19 \pm 0.06^{\mathrm{c}}$ & $0.98 \pm 0.01^{\mathrm{e}}$ & $0.84 \pm 0.08^{\mathrm{e}}$ \\
\hline
\end{tabular}

Values are means \pm standard deviations. Data with the same superscript letter were not significantly different $(p<0.05$; Tukey test)

Table 3 Production of cellulase by A. niger using acid-treated agricultural residues

\begin{tabular}{|c|c|c|c|c|}
\hline $\begin{array}{l}\text { S/ } \\
\text { no. }\end{array}$ & $\begin{array}{l}\text { Substrate } \\
\text { (acid treated) }\end{array}$ & $\begin{array}{l}\text { CMCase } \\
\text { (U/g) }\end{array}$ & $\begin{array}{l}\text { FPase } \\
(\mathrm{U} / \mathrm{g})\end{array}$ & $\begin{array}{l}\beta \text {-glucosidase } \\
(\mathrm{U} / \mathrm{g})\end{array}$ \\
\hline 1 & $\begin{array}{l}\text { Finger millet } \\
\text { hulls }\end{array}$ & $0.80 \pm 0.20^{\mathrm{a}, \mathrm{b}}$ & $0.90 \pm 0.02^{\mathrm{a}, \mathrm{b}}$ & $0.31 \pm 0.05^{\mathrm{a}, \mathrm{b}}$ \\
\hline 2 & Sorghum hulls & $0.96 \pm 0.04^{\mathrm{b}}$ & $0.99 \pm 0.07^{\mathrm{b}}$ & $0.46 \pm 0.01^{\mathrm{a}}$ \\
\hline 3 & Banana peels & $0.50 \pm 0.03^{\mathrm{a}, \mathrm{c}}$ & $0.71 \pm 0.01^{\mathrm{a}}$ & $1.01 \pm 0.08^{\mathrm{c}}$ \\
\hline 4 & Corn stalk & $1.08 \pm 0.10^{\mathrm{b}}$ & $0.83 \pm 0.05^{\mathrm{a}, \mathrm{b}}$ & $1.09 \pm 0.10^{\mathrm{c}, \mathrm{d}}$ \\
\hline 5 & Cassava peels & $2.30 \pm 0.30^{\mathrm{d}}$ & $1.70 \pm 0.13^{\mathrm{c}, \mathrm{d}}$ & $1.27 \pm 0.11^{\mathrm{d}}$ \\
\hline 6 & Saw dust & $1.10 \pm 0.20^{\mathrm{b}}$ & $0.98 \pm 0.02^{\mathrm{b}}$ & $0.72 \pm 0.05^{\mathrm{e}}$ \\
\hline 7 & Sheanut cake & $0.31 \pm 0.01^{\mathrm{c}}$ & $0.25 \pm 0.12^{\mathrm{e}}$ & $0.13 \pm 0.01^{\mathrm{b}}$ \\
\hline 8 & Rice straw & $3.20 \pm 0.06^{\mathrm{e}}$ & $2.10 \pm 0.08^{\mathrm{g}}$ & $2.00 \pm 0.14^{\mathrm{f}}$ \\
\hline 9 & Soybean hulls & $3.12 \pm 0.14^{\mathrm{e}}$ & $2.05 \pm 0.07^{\mathrm{f}, \mathrm{g}}$ & $1.99 \pm 0.01^{\mathrm{f}}$ \\
\hline 10 & $\begin{array}{c}\text { Sugarcane } \\
\text { bagasse }\end{array}$ & $3.00 \pm 0.10^{\mathrm{e}}$ & $1.85 \pm 0.05^{\mathrm{d}, \mathrm{f}}$ & $1.92 \pm 0.03^{\mathrm{f}}$ \\
\hline 11 & Groundnut husk & $2.87 \pm 0.26^{\mathrm{e}}$ & $1.61 \pm 0.14^{\mathrm{c}}$ & $1.96 \pm 0.11^{\mathrm{f}}$ \\
\hline
\end{tabular}

Values are means \pm standard deviations. Data with the same superscript letter were not significantly different $(p<0.05$; Tukey test) 
Table 4 Production of cellulase by A. niger using oxidative treatment of agricultural residues

\begin{tabular}{lllll}
\hline $\begin{array}{l}\mathrm{S} / \\
\text { no. }\end{array}$ & $\begin{array}{l}\text { Substrate } \\
\left(\mathrm{H}_{2} \mathrm{O}_{2} \text { treated }\right)\end{array}$ & $\begin{array}{l}\text { CMCase } \\
(\mathrm{U} / \mathrm{g})\end{array}$ & $\begin{array}{l}\text { FPase } \\
(\mathrm{U} / \mathrm{g})\end{array}$ & $\begin{array}{l}\beta \text {-glucosidase } \\
(\mathrm{U} / \mathrm{g})\end{array}$ \\
\hline 1 & $\begin{array}{l}\text { Finger millet } \\
\text { hulls }\end{array}$ & $1.43 \pm 0.16^{\mathrm{a}, \mathrm{b}}$ & $0.91 \pm 0.01^{\mathrm{a}}$ & $1.10 \pm 0.15^{\mathrm{a}, \mathrm{b}, \mathrm{c}}$ \\
2 & Sorghum hulls $^{2}$ & $1.55 \pm 0.02^{\mathrm{a}, \mathrm{b}}$ & $1.00 \pm 0.03^{\mathrm{a}}$ & $0.77 \pm 0.20^{\mathrm{a}, \mathrm{b}}$ \\
3 & Banana peels & $1.79 \pm 0.13^{\mathrm{a}, \mathrm{b}}$ & $1.10 \pm 0.22^{\mathrm{a}}$ & $1.01 \pm 0.10^{\mathrm{a}, \mathrm{b}, \mathrm{c}}$ \\
4 & Corn stalk & $2.01 \pm 0.02^{\mathrm{a}}$ & $1.32 \pm 0.01^{\mathrm{a}, \mathrm{b}}$ & $1.27 \pm 0.10^{\mathrm{c}}$ \\
5 & Cassava peels & $3.04 \pm 0.07^{\mathrm{c}}$ & $1.48 \pm 0.11^{\mathrm{a}, \mathrm{b}}$ & $1.25 \pm 0.03^{\mathrm{b}, \mathrm{c}}$ \\
6 & Saw dust & $1.65 \pm 0.02^{\mathrm{a}, \mathrm{b}}$ & $1.47 \pm 0.06^{\mathrm{a}, \mathrm{b}}$ & $1.03 \pm 0.03^{\mathrm{a}, \mathrm{b}, \mathrm{c}}$ \\
7 & Sheanut cake & $1.20 \pm 0.30^{\mathrm{b}}$ & $0.64 \pm 0.04^{\mathrm{a}}$ & $0.68 \pm 0.10^{\mathrm{a}}$ \\
8 & Rice straw & $5.30 \pm 0.40^{\mathrm{d}}$ & $3.60 \pm 0.33^{\mathrm{c}}$ & $2.31 \pm 0.14^{\mathrm{d}}$ \\
9 & Soybean hulls & $5.65 \pm 0.33^{\mathrm{d}}$ & $3.58 \pm 0.11^{\mathrm{c}}$ & $3.16 \pm 0.36^{\mathrm{e}}$ \\
10 & Sugarcane & $4.61 \pm 0.23^{\mathrm{e}}$ & $2.93 \pm 0.65^{\mathrm{c}, \mathrm{d}}$ & $2.22 \pm 0.24^{\mathrm{d}}$ \\
& bagasse & & & \\
11 & Groundnut & $4.43 \pm 0.15^{\mathrm{e}}$ & $2.39 \pm 0.95^{\mathrm{d}}$ & $2.04 \pm 0.07^{\mathrm{d}}$ \\
& husk & & & \\
\hline
\end{tabular}

Values are means \pm standard deviations. Data with the same superscript letter were not significantly different ( $p<0.05$; Tukey test)

Table 5 Production of cellulase by A. niger using alkali-treated agricultural residues

\begin{tabular}{|c|c|c|c|c|}
\hline $\begin{array}{l}\text { S/ } \\
\text { no. }\end{array}$ & $\begin{array}{l}\text { Substrate } \\
\text { (alkali treated) }\end{array}$ & $\begin{array}{l}\text { CMCase } \\
(\mathrm{U} / \mathrm{g})\end{array}$ & $\begin{array}{l}\text { FPase } \\
(\mathrm{U} / \mathrm{g})\end{array}$ & $\begin{array}{l}\beta \text {-glucosidase } \\
(\mathrm{U} / \mathrm{g})\end{array}$ \\
\hline 1 & $\begin{array}{l}\text { Finger millet } \\
\text { hulls }\end{array}$ & $1.63 \pm 0.10^{\mathrm{a}, \mathrm{b}}$ & $1.05 \pm 0.10^{\mathrm{a}}$ & $1.30 \pm 0.04^{\mathrm{a}, \mathrm{b}}$ \\
\hline 2 & Sorghum hulls & $1.64 \pm 0.08^{\mathrm{a}, \mathrm{b}}$ & $1.11 \pm 0.20^{\mathrm{a}}$ & $0.99 \pm 0.05^{\mathrm{a}}$ \\
\hline 3 & Banana peels & $2.00 \pm 0.02^{\mathrm{a}}$ & $1.96 \pm 0.10^{\mathrm{b}}$ & $1.22 \pm 0.01^{\mathrm{a}, \mathrm{b}}$ \\
\hline 4 & Corn stalk & $3.30 \pm 0.15^{\mathrm{c}}$ & $2.74 \pm 0.09^{c}$ & $2.09 \pm 0.01^{\mathrm{c}}$ \\
\hline 5 & Cassava peels & $4.10 \pm 0.01^{\mathrm{d}}$ & $3.03 \pm 0.04^{\mathrm{c}, \mathrm{d}}$ & $2.93 \pm 0.11^{\mathrm{d}}$ \\
\hline 6 & Saw dust & $3.04 \pm 0.12^{\mathrm{c}}$ & $1.81 \pm 0.06^{\mathrm{b}}$ & $1.77 \pm 0.10^{\mathrm{b}, \mathrm{c}}$ \\
\hline 7 & Sheanut cake & $1.34 \pm 0.03^{\mathrm{b}}$ & $0.89 \pm 0.10^{\mathrm{a}}$ & $0.87 \pm 0.02^{\mathrm{a}}$ \\
\hline 8 & Rice straw & $8.81 \pm 0.21^{\mathrm{e}}$ & $5.23 \pm 0.19^{\mathrm{e}}$ & $4.10 \pm 0.62^{\mathrm{e}}$ \\
\hline 9 & Soybean hulls & $9.91 \pm 0.04^{\mathrm{f}}$ & $6.20 \pm 0.13^{\mathrm{f}}$ & $5.69 \pm 0.29^{f}$ \\
\hline 10 & $\begin{array}{c}\text { Sugarcane } \\
\text { bagasse }\end{array}$ & $8.33 \pm 0.50^{\mathrm{e}}$ & $5.06 \pm 0.06^{\mathrm{e}}$ & $4.09 \pm 0.44^{\mathrm{e}}$ \\
\hline 11 & $\begin{array}{l}\text { Groundnut } \\
\text { husk }\end{array}$ & $5.88 \pm 0.16^{\mathrm{g}}$ & $3.08 \pm 0.09^{\mathrm{d}}$ & $3.97 \pm 0.01^{\mathrm{e}}$ \\
\hline
\end{tabular}

Values are means \pm standard deviations. Data with the same superscript letter were not significantly different $(p<0.05$; Tukey test)

aids in increasing the substrate's surface area and decreasing cellulose crystallinity which make the available carbon sources accessible for microbial utilization (Kumar et al. 2009). In addition, A. niger is a versatile organism with strong ability to utilize the available nutrients present in different agricultural residues and to produce several enzyme systems during the bioconversion process. A clear trend was seen in all the three cellulolytic enzyme systems (CMCase, FPase and $\beta$-glucosidase), where their lowest activities were found in sheanut cake. However, the values were not statistically different from those of finger millet hulls, sorghum hulls and corn stalk. Rice straw and sugarcane bagasse showed the highest activities of $1.76 \pm 0.08,1.22 \pm 0.03$, $0.91 \pm 0.04$ and $1.66 \pm 0.19,1.01 \pm 0.07,0.84 \pm 0.01 \mathrm{U} /$ $\mathrm{g}$ in terms of CMCase, FPase and $\beta$-glucosidase, respectively.

Acid pretreatment (Table 3) yielded higher cellulolytic enzyme production than the unpretreated substrates (Table 2), and several disadvantages have been linked with its utilization including formation of degradation products of pentoses, hexoses and other compounds, such as furfural, hydroxyl-methyl furfural, acetic acid, formic acid, levulinic acid, which affect microbial bioconversion processes (Balat et al. 2008). Thus, soybean hulls appeared to have higher percentage improvement in cellulase production with 58,51 and $59 \%$ (equivalent to $3.12 \pm 0.14$, $2.05 \pm 0.07$ and $1.99 \pm 0.01 \mathrm{U} / \mathrm{g}$ ) for CMCase, FPase and $\beta$-glucosidase, respectively, when compared with the unpretreated substrates. Other residues with improved cellulolytic activities following the acid pretreatment include rice straw, sugarcane bagasse and groundnut husk.

In case of oxidative pretreatment using $\mathrm{H}_{2} \mathrm{O}_{2}$, increment in cellulase production was observed in all the residues (Table 4), and maximum cellulase production was found in soybean hulls with $5.63 \pm 0.33 \mathrm{U} / \mathrm{g}$ for CMCase, $3.58 \pm 0.11 \mathrm{U} / \mathrm{g}$ for FPase and $3.16 \pm 0.36 \mathrm{U} / \mathrm{g} \beta$-glucosidase followed by rice straw with $5.30 \pm 0.40$, $3.60 \pm 0.33$ and $2.31 \pm 0.14 \mathrm{U} / \mathrm{g}$ for CMCase, FPase and $\beta$-glucosidase, respectively. Sheanut cake had the least cellulase production; this is because of its compositions (especially the residual oil content) as it was reported to be a potential substrate for lipase production by A. niger (Salihu et al. 2013). Also, Hon and Shiraishi (2001) noted that several reactions may occur during oxidative pretreatment which include displacement of side chains, electrophilic substitution and cleavage of alkyl aryl ether linkages or oxidative cleavage of aromatic nuclei. These reactions help in removing the hemicellulose and lignin by increasing the accessibility of the cellulose (Singh and Bishnoi 2013). However, the presence of these hydrolysates may cause some inhibitory effects that result in lower activities compared to alkaline pretreatment method.

Based on all the results, alkaline pretreated residues (Table 5) showed the highest cellulolytic enzyme production compared to the unpretreated, acid- and $\mathrm{H}_{2} \mathrm{O}_{2}$-treated residues. This could be related to minimum amount of lignin content and increased internal surface area as well as fiber distension in the alkali-treated residues (Sun and Cheng 2002). Thus, the available cellulose and hemicellulose following this pretreatment favor microbial growth and enzyme production.

Maximum cellulolytic enzyme production was observed in alkali-treated soybean hulls of $9.91 \pm 0.04,6.20 \pm 0.13$ and $5.69 \pm 0.29 \mathrm{U} / \mathrm{g}$ in terms of CMCase, FPase and 


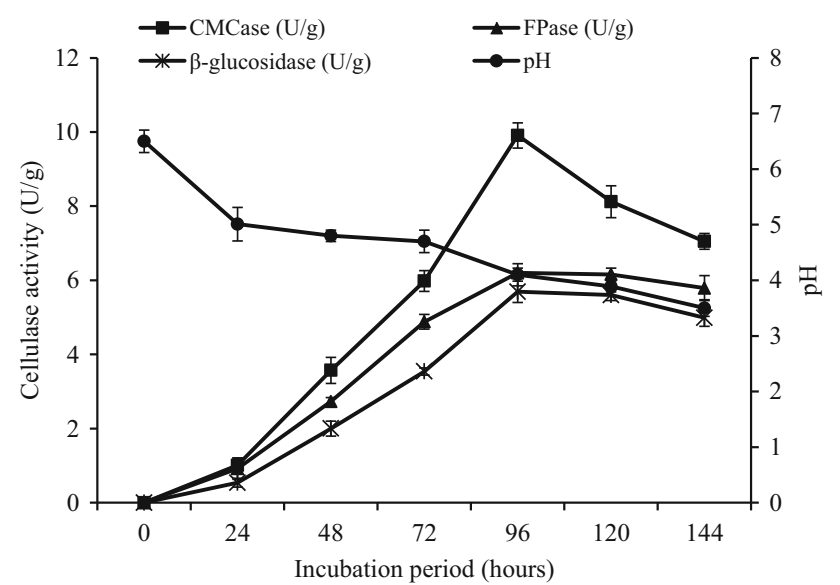

Fig. 1 Cellulase production in alkali-treated soybean hulls based on initial $\mathrm{pH}$ of 6.5 at different fermentation time

$\beta$-glucosidase, respectively. Generally, soybean hulls were reported to consist of cellulose (46-51\%), hemicellulose (16-18\%) and lignin (1.4-2\%), making them to be a good source of fermentable sugars for utilization in formation of several value-added products (Corredor et al. 2008). However, the composition of soybean hulls used in this study was lower in terms of cellulose $(35 \pm 0.12 \%)$ and higher in lignin content $(4 \pm 0.19 \%)$. The hemicellulose was found to be within the range $(16 \pm 0.21 \%)$ as indicated in Table 1.

Most studies where higher cellulase production was reported involved the use of additional medium components to enhance the production. Maximum FPase and $\beta$-glucosidase activities of $133.68 \pm 5.44$ and $60.09 \pm 3.43 \mathrm{U} /$ $\mathrm{g}$, respectively, were obtained by A. niger NRRL-567 when apple pomace was supplemented with $\mathrm{CuSO}_{4}$ and veratryl alcohol. However, supplementation of apple pomace with lactose resulted in better CMCase activity of $172.31 \pm 14.21 \mathrm{U} / \mathrm{g}$ (Dhillon et al. 2012)

The findings in this study agree with what were reported by Zhang et al. (2012) using acid and alkali-treated samples of switch grass, corn stover and anaerobically digested manure fiber. The three alkali-treated samples gave higher cellulase activities than acid-treated ones. Also, results obtained when using alkali-treated coir pith, a by-product of coir fiber extraction process for cellulase production by A. nidulans showed maximum CMCase, FPase and cellobiase activities of $28.64,10.23$ and $4.31 \mathrm{U} / \mathrm{g}$, respectively (Jabasingh 2011).

Effect of incubation period on alkali-treated soybean hulls as the most promising residues with higher cellulolytic enzyme activities was studied, and maximum production was observed after 96 h (Fig. 1). Further increase in incubation period resulted in decreased enzyme activities. Thus, incubation period of $96 \mathrm{~h}$ was found to be sufficient for maximum cellulase production in alkalitreated soybean hulls.

Similarly, $\mathrm{pH}$ of the fermentation medium decreased from the initial $\mathrm{pH}$ of 6.5 to $4.1 \pm 0.2$ (at $96 \mathrm{~h}$ ) when the cellulase production was at its optimum. The $\mathrm{pH}$ decreased further to $3.5 \pm 0.15$ at the end of the experiment (144 h) as indicated in Fig. 1. The decrease in $\mathrm{pH}$ could be related to the formation of acidic metabolite during the bioconversion process, and the final $\mathrm{pH}$ of 3.5 may still be within the favorable condition for efficient fungal growth as suggested by Molla et al. (2004). Similar trend in pH reduction was also reported by Alam et al. (2009) during cellulase production by $T$. harzianum T2008 using oil palm empty fruit bunches as substrate.

Further studies in optimizing the medium composition as well as process parameters for enhanced cellulase production using soybean hulls as novel substrate are currently being considered.

\section{Conclusion}

Eleven agricultural residues were considered for cellulolytic enzyme production using three pretreatment methods (acid, oxidative and alkaline). Alkaline pretreatment was found to be the most efficient method with higher enzyme production. Soybean hulls showed higher activities in terms of CMCase, FPase and $\beta$-glucosidase after $96 \mathrm{~h}$ of incubation. Using this cheap and renewable residue for cellulolytic enzyme production by A. niger boosts its economic value which is not comparable with its current use as animal feed.

Acknowledgments The authors are grateful to the technical staff of Department of Biochemistry ABU Zaria and Department of Biotechnology Engineering IIUM for their assistance and cooperation.

Conflict of interest The authors declare that they have no conflict of interest

Open Access This article is distributed under the terms of the Creative Commons Attribution License which permits any use, distribution, and reproduction in any medium, provided the original author(s) and the source are credited.

\section{References}

Alam MZ, Mamun AA, Qudsieh IY, Muyibi SA, Salleh HM, Omar NM (2009) Solid state bioconversion of oil palm empty fruit bunches for cellulase enzyme production using a rotary drum bioreactor. Biochem Eng J 46:61-64

Ariffin H, Hassan MA, Md Shah UK, Abdullah N, Ghazali FM, Shirai Y (2008) Production of bacterial endoglucanase from pretreated oil palm empty fruit bunch by Bacillus pumilus EB3. J Biosci Bioeng 106(3):231-236 
Arora D, Sharma R (2009) Comparative ligninolytic potential of Phlebia species and their role in improvement of in vitro digestibility of wheat straw. J Anim Feed Sci 18:151-161

Balat M, Balat H, Oz C (2008) Progress in bioethanol processing. Prog Energ Combust 34:551-573

Bansal N, Tewari R, Soni R, Soni SK (2012) Production of cellulases from Aspergillus niger NS-2 in solid state fermentation on agricultural and kitchen waste residues. Waste Manag 32:1341-1346

Bhat MK (2000) Cellulases and related enzymes in biotechnology. Biotechnol Adv 18:355-383

Bhat MK, Bhat S (1997) Cellulose degrading enzymes and their potential industrial application. Biotechnol Adv 15:583-620

Clarke AJ (1997) Biodegradation of cellulose: enzymology and biotechnology. Technomic Publishing Company, USA

Corredor DY, Sun XS, Salazar JM, Hohn KL, Wang D (2008) Enzymatic hydrolysis of soybean hulls using dilute acid and modified steam-explosion pretreatments. J Biobased Mater Bio 2:43-50

Dashtban M, Schraft H, Qin W (2009) Fungal bioconversion of lignocellulosic residues; opportunities and perspectives. Int $\mathbf{J}$ Biol Sci 5(6):578-595

Datta R (1981) Acidogenic fermentation of lignocellulose-acid yield and conversion of components. Biotechnol Bioeng 23:2167-2170

Dhillon GS, Kaur S, Brar SK, Verma M (2012) Potential of apple pomace as a solid substrate for fungal cellulase and hemicellulase bioproduction through solid-state fermentation. Ind Crops Prod 38:6-13

Diaz AB, de Ory I, Caro I, Blandino A (2012) Enhance hydrolytic enzymes production by Aspergillus awamori on supplemented grape pomace. Food Bioprod Process 90:72-78

Ghose TK (1987) Measurement of cellulase activities. Pure Appl Chem 59(2):257-268

Hon DNS, Shiraishi N (2001) Wood and cellulosic chemistry, 2nd edn. Dekker, New York

Jabasingh SA (2011) Utilization of pretreated coir pith for the optimized bioproduction of cellulase by Aspergillus nidulans. Int Biodeterior Biodegrad 65:1150-1160

Khan MMH, Ali S, Fakhrul-razi A, Alam MD (2007) Use of fungi for the bioconversion of rice straw into cellulase enzyme. J Environ Sci Health Part B 42:381-386

Kumar P, Barrett DM, Deliche MJ, Stroeve P (2009) Methods for pretreatment of lignocellulosic biomass for efficient hydrolysis and biofuel production. Ind Eng Chem Res 48(8):3713-3729

Liu Y-T, Luo Z-Y, Long C-N, Wang H-D, Long M-N, Hu Z (2011) Cellulase production in a new mutant strain of Penicillium decumbens ML-017 by solid state fermentation with rice bran. New Biotechnol 28(6):733-737

Maeda RN, Barcelos CA, Melo LM, Anna S, Pereira N Jr (2013) Cellulase production by Penicillium funiculosum and its application in the hydrolysis of sugar cane bagasse for second generation ethanol production by fed batch operation. J Biotechnol 163:38-44

Mandels M, Andreotti RE, Roche C (1976) Measurements of saccharifying cellulases. Biotechnol Bioeng Symp 6:21-23

Molla AH, Fakhru'l-Razi A, Alam MZ (2004) Evaluation of solid-state bioconversion of domestic wastewater sludge as a promising environmental-friendly disposal technique. Water Res 38:4143-4152

Saha BC (2004) Production, purification and properties of endoglucanase from a newly isolated strain of Mucor circinelloides. Process Biochem 39:1871-1876

Salihu A, Bala M, Bala SM (2013) Application of Plackett-Burman experimental design for lipase production by Aspergillus niger using shea butter cake. ISRN Biotechnol. doi:10.5402/2013/ 718352

Sánchez C (2009) Lignocellulosic residues: biodegradation and bioconversion by fungi. Biotechnol Adv 27(2):185-194

Sehnem NT, de Bittencourt LR, Camassola M, Dillon AJP (2006) Cellulase production by Penicillium echinulatum on lactose. Appl Microbiol Biotechnol 72:163-167

Silverstein RA, Chen Y, Sharma-Shivappa RR, Boyette MD, Osborne J (2007) A comparison of chemical pretreatment methods for improving saccharification of cotton stalks. Bioresour Technol 98:3000-3011

Singh A, Bishnoi NR (2013) Comparative study of various pretreatment techniques for ethanol production from water hyacinth. Ind Crops Prod 44:283-289

Sohail M, Siddiqi R, Ahmad A, Khan SA (2009) Cellulase production from Aspergillus niger MS82: effect of temperature and $\mathrm{pH}$. New Biotechnol 25(6):6437-6441

Sun Y, Cheng J (2002) Hydrolysis of lignocellulosic materials for ethanol production: a review. Bioresour Technol 83:1-11

Wen Z, Liao W, Chen S (2005) Production of cellulase/ $/$-glucosidase by the mixed fungi culture of Trichoderma reesei and Aspergillus phoenicis on dairy manure. Appl Biochem Biotechnol 121(124):93-104

Wyman CE (1994) Ethanol from lignocellulosic biomass: technology, economics and opportunities. Bioresour Technol 50:3-16

Xu Z, Bai Y, Xu X, Shi J, Tao W (2005) Production of alkali-tolerant cellulase-free xylanase by Pseudomonas sp. WLUN024 with wheat bran as the main substrate. World J Microbiol Biotechnol 21:575-581

Zhang L, Liu Y, Niu X, Liu Y, Liao W (2012) Effects of acid and alkali treated lignocellulosic materials on cellulase/xylanase production by Trichoderma reesei Rut C-30 and corresponding enzymatic hydrolysis. Biomass Bioenerg 37:16-24

Zhao X, Zhang L, Liu D (2008) Comparative study on chemical pretreatment methods for improving enzymatic digestibility of crofton weed stem. Bioresour Technol 99:3729-3736 